\title{
The Impact of Awareness Campaigns on Combating the Food Wasting Behavior of Consumers
}

\author{
Cătălina Chinie ${ }^{1, * \mathbb{D}}$, Isabelle Biclesanu ${ }^{1}$ and Francesco Bellini ${ }^{2}$ (D) \\ 1 Faculty of Business Administration in Foreign Languages, Bucharest University of Economic Studies, \\ 010731 Bucharest, Romania; isabelle.bn@pm.me \\ 2 Department of Management, Sapienza University of Rome, 00161 Rome, Italy; francesco.bellini@uniroma1.it \\ * Correspondence: catalina.chinie@fabiz.ase.ro
}

check for updates

Citation: Chinie, C.; Biclesanu, I.; Bellini, F. The Impact of Awareness Campaigns on Combating the Food Wasting Behavior of Consumers. Sustainability 2021, 13, 11423. https:// doi.org/10.3390/su132011423

Academic Editors: Daniele Curzi and Alessia Cavaliere

Received: 25 August 2021

Accepted: 12 October 2021

Published: 15 October 2021

Publisher's Note: MDPI stays neutral with regard to jurisdictional claims in published maps and institutional affiliations.

Copyright: (c) 2021 by the authors. Licensee MDPI, Basel, Switzerland. This article is an open access article distributed under the terms and conditions of the Creative Commons Attribution (CC BY) license (https:/ / creativecommons.org/licenses/by/ $4.0 /)$.

\begin{abstract}
As food loss and food waste continue to be social, economic, and environmental issues, governments, private companies, and nonprofit organizations have started initiatives in order to raise awareness about this topic. Food waste occurs mainly at the consumer level, so information campaigns have been carried out in the media, in shops, or online, in order to point out the extent of the problem, its effects, and to educate consumers as to how to generate less waste. Although some awareness campaigns were conducted in Romania, mostly by the private sector, but also by governmental institutions, these efforts are still few in comparison with other European countries. Research of this topic has also started to increase, but the effects of the campaigns conducted in Romania have not been thoroughly assessed. In an effort to evaluate the effectiveness of these campaigns on consumer food-wasting behavior, we have carried out a study among Romanian citizens, based on a survey. The data were analyzed using the chi-square test and the probit regression model. The results indicate that most respondents already self-assessed their food waste as small to moderate, regardless of their familiarity with food waste campaigns, and it might be the case that only their additional actions to reduce food waste are linked with them coming across food waste reduction campaigns.
\end{abstract}

Keywords: food waste; awareness campaign; consumer behavior; food loss; food supply

\section{Introduction}

Food waste is a problem that has become a topic of concern for international institutions, such as the Food and Agriculture Organization (FAO), and the European Commission, with an extensive impact at the social, economic, and environmental levels [1-3]. Reducing food waste is correlated with the 2nd and the 12th Sustainable Development Goals of the United Nations: "Zero Hunger" and "Responsible Consumption and Production", respectively. The European Union is committed to reducing food waste by half by 2030 and, as part of its strategy, it established the EU Platform on Food Losses and Food Waste in 2016, where prevention measures can be defined, best practices can be shared, and progress can be evaluated over time [4]. Reducing food waste has also been placed on the agenda of national policymakers, within programs such as the "Waste Prevention" program of the German government, the "Stop Food Waste" program in Ireland, or the "Italian National Plan for Food Waste Prevention". Denmark's awarded program, "Stop Wasting Food", was founded at the private initiative of Selina Juul in 2008 and has since managed to attract the engagement of the Denmark government, high profile CEOs, and private companies. Romania has also had some initiatives regarding the reduction of food waste, but with a smaller echo than those in the previously mentioned countries. In 2013, the Romanian Ministry of Agriculture organized a workshop where more than 20 public institutions discussed strategic measures to reduce food waste [5]. One of these measures was the creation of an online platform for online communication. In 2021, the Ministry of Agriculture used its website to publish informational materials, regulations, and the 
operators that collect food to be further donated or commercialized to vulnerable social categories [6], but no communication platform that could be used as a promotional tool was developed.

Food waste occurs along the entire supply chain, in the earlier stages, in the case of developing countries, and in the later stages, at the consumer level, within developed countries [7-10]. The research of Beretta et al. [11] underlines that more information regarding where food waste occurs in the supply chain is needed, as the impact of food waste at the lower stages of the supply chain also encompasses the negative effects of transportation, storage, packaging, and processing. Garcia-Herrero et al. [12] developed a Nutritional Food Losses Footprint (NFLF), which distinguishes between food losses in the earlier stages (from cradle to gate), and the later stages (from gate to grave), of the supply chain. The categorization is made to enable different food waste reduction measures for the different stages of the supply chain.

A growing body of literature has addressed the causes and drivers of food waste among consumers [13-17]. The causes of food waste among consumers include: offering the family healthy and ample food; the desire to minimize inconveniencies; the lack of awareness and information [18]; refusing to buy food that does not look optimal anymore [19]; refusing to buy food that is approaching the "best before" date; as well as buying more food than is needed and not consuming it in time [20].

A holistic approach regarding the drivers of food waste must be considered, i.e., decisions that are taken at the retail level may drive food waste at the consumer level [21].

Various food waste mitigation measures can be used along the food wastage pyramid [22], from the most to the least environmentally friendly measures: reduction, re-use, recycle, recovery, and disposal.

Information campaigns can be used as instruments to support social change. Reynolds et al. [23] have analyzed 17 interventions that claimed to have reduced food waste, among which they looked at the effectiveness of awareness campaigns on a small sample size, which resulted in up to a $28 \%$ food waste reduction. Such campaigns are based on information and on the building capacities of the consumers [21]. Previous studies regarding campaigns to reduce food waste have been conducted in Western and Northern Europe, Northern and Southern America, the Middle East, and Asia [21,24-27]. Although the phenomenon of food waste has been analyzed in Romania [28-30], to the best knowledge of the authors, there have been no studies regarding the impact of awareness campaigns on food waste in this country. As the topic of food waste is gaining attention, an empirical study regarding the effects of the awareness campaigns conducted so far would help organizations and policymakers design better actions and measures for food waste reduction.

The main initiatives to raise awareness about food waste in Romania have been carried out by nonprofit organizations, and with the support of retailers, such as Food Waste Romania and Food Waste Combat.

Studying the impact that information campaigns have on the behavior of people can support decisions regarding the measures that must be taken in order to effectively and efficiently reduce food waste.

This research is part of an ampler study assessing the role of intelligent systems in reducing consumer food waste. The current paper's objective is to discover the relationship between food waste awareness campaigns and consumer behavior regarding food waste, based on three research questions:

RQ1: what is the impact of awareness campaigns over the self-assessed amount of food waste?

$\mathrm{RQ2}$ : what is the impact of awareness campaigns over the actions taken by consumers to reduce food waste in the past year?

RQ3: what is the impact of the actions taken by consumers to reduce their food waste on their self-assessed amount of food waste? 


\section{Literature Review}

\subsection{The Food Waste Phenomenon}

Food loss is defined by the Food and Agriculture Organization of the United Nations (FAO) as "the decrease in the mass (dry matter quantity) or nutritional value (quality) of food that was originally intended for human consumption" [22]. Food waste is defined by the FAO as "food appropriate for human consumption being discarded, whether or not after it is kept beyond its expiry date or left to spoil" [22]. In this paper, we refer to the food wasted at the consumer level.

Many international initiatives for reducing food loss and food waste have taken place, given the high importance of the topic [31]. The FAO's "Sustainable Development Goal $12.3^{\prime \prime}$ is aimed at reducing food loss across the supply chain and halving per capita food waste at the retail and consumer levels by 2030 [32], as food waste is considered a major contributor to the three planetary crises: (1) nature and biodiversity loss; (2) climate change; and (3) pollution and waste [33]. For example, in 2015, food waste was estimated to be the cause of $8 \%$ of the global anthropogenic greenhouse gas emissions, making the impact of food waste emissions on global warming the equivalent of almost $87 \%$ of the global road transport emissions [34].

Some European Union (EU) legislation is, directly or indirectly, related to food waste. However, it creates a low impact as it contradicts the interests of the stakeholders and, thus, in-depth research into the consequences and interactions of food waste legislation should be performed for more harmonious integration [35]. As for Romania, its food waste legislation is based on the EU legislation [36]. For example, Law no. 217/2016 [37], on reducing food waste, states that all food industry economic operators should initiate food waste reduction campaigns, as well as become involved in such campaigns developed by the authorities.

Around 931 million tons of food waste were generated globally in 2019, 61\% in households, 26\% in food services, and 13\% in retail [33]. According to Statista [38], an average of $74 \mathrm{~kg}$ of food/person was wasted worldwide in 2019. Food waste has been deemed especially problematic in high-income countries because of wasteful food distribution channels and the consumption patterns of citizens [34]. In developed countries, consumer food accounts for a big part of the total food waste [10].

On the basis of the 2019 data for Europe, around $72.75 \mathrm{~kg}$ of food/person/year are estimated to be wasted on average at the household level [33]. However, Eurostat [39] concluded that $6.8 \%$ of European Union citizens could not afford a meal that includes meat, fish, chicken, or vegetarian equivalents every second day in 2019 (the percentage has been declining since 2012, when it was approximately 11\%). Globally, almost half of all deaths in children under five years old are estimated to be caused by undernourishment-related diseases, and around 822 million people suffer from poor nutrition [40]. Developments in digitization and infrastructure could help in reducing food waste by connecting the potential sources of food waste with consumers in need of food [29,41].

For Romania, UNEP estimated, based on 2019 data, that around $70 \mathrm{~kg}$ of food are wasted per person per year at the household level [33]. Household food waste was around $10.5 \%$ in 2016 [42], while, in 2020, the level was reduced to $6.5 \%$ [43]. The consumer price index for food products was $116.39 \%$ for December 2016 (i.e., the reference period) to December 2020 (i.e., the comparison period) [44], while the average net monthly earnings per total economy for the same period was 153.78\% [45], suggesting an increase in the population's purchasing power for the period. Thus, the reduction in the food waste of Romanian citizens for 2020, compared with 2016, could be the result of public awareness campaigns, the COVID-19 pandemic influencing consumer behavior, and/or differences in the research methodology and demographics.

Regarding the psychological aspects of food waste, the study of Graham-Rowe et al. [46] has shown that people are concerned about food waste. Throwing away food enacts a feeling of guilt among consumers [47]. Looking specifically at Romanian consumers, Cantaragiu [48] discovered that there are major differences between the genders and age 
segments in their attitudes towards food waste (e.g., 20-30 year-old women are more likely to report feelings of guilt after throwing away food and see food waste as part of the social inequality phenomenon, while older women associate food waste prevention with financial responsibility). Another study characterized Romanian consumers based on three clusters: (1) careless - consumers who have a low level of education, throw away food, and come from rural areas; (2) precautious-consumers who have mixed sociodemographic characteristics, do not throw away food, and are informed about food waste issues; and (3) ignorant-consumers who have a high level of education, throw away food, and come from urban areas [28]. Seemingly, the level of income or education is not linked to adopting anti-waste behaviors. Moreover, it was discovered that Romanian citizens who waste food do not report feelings of guilt for their personal actions but, instead, consider that the higher levels in the food supply chain are responsible [28].

Fully understanding the causes of food waste requires an integrated approach that also accounts for the transactions and interactions along the supply chain $[49,50]$. This importance was underlined by the work of Aschemann-Witzel et al. [21], and Lee [51], who showed that the amount of food wasted in households is correlated with actions taken at the retailer level, such as selling in bulk packaging or using promotions.

Researchers have studied the causes of consumer food waste and the barriers to reducing this problem. Schanes et al. [16] synthetized the main food waste reasons into two main categories, based on their literature review of prior studies: (1) understandings and perceptions of food waste, and (2) food-related household practices and routines, i.e., planning, shopping, storage, cooking, eating, managing leftovers, assessing edibility, and disposal [16]. Leverenz et al. [14] identified similar causes, related to cooking, storage, and using leftovers or the bad handling of food products. Another cause of consumer food waste is rooted in the core values of consumers. For instance, Minton et al. [52] discovered that people who adopt restrictive religious norms (e.g., fasting) produce a higher level of food waste, compared with people who identify with supportive religious norms (e.g., food sharing), who show more interest in reducing their food waste. Wakefield and Axon [53] have identified the lack of education regarding food waste as a barrier to reducing food waste at the household level, as well as excess packaging, cultural norms, and social marketing, while Janssens et al. [54] consider that the lack of food preparation planning seems to be among the most important barriers to reducing the food-wasting behavior of consumers. As for Romanian consumers, one study identified the main reasons for throwing away food (i.e., expiration date, a long refrigerator storage period, inadequate storage, food appearance deterioration), and recommended the implementation of education campaigns and shopping list planning as possible solutions [30].

\subsection{Measures to Reduce Food Waste}

As the awareness regarding the food waste phenomenon has grown, measures to reduce it have been studied and used at the governmental level, as well as at the private and consumer levels.

Policymakers try to shape consumer behavior based on four primary strategies: (1) the "punishment" approach; (2) the "rewards-based" approach; (3) the "persuasion" strategy; and (4) the "social communication" strategy, where consumer behavior is influenced by other people [55]. The activities performed by governments in order to reduce food waste, as reviewed by Auld et al. [56], include eco-labels, environmental management system standards and audits, voluntary programs, and other governmental mechanisms that involve businesses and NGOs.

The actions aimed at reducing food loss and waste can be categorized as: (1) prevention; (2) recovery; and (3) recycling actions, also referred to as the food waste hierarchy [57]. Preventive actions are at the base of the hierarchy and are considered the most efficient measures [20], while recycling should be the last resort when dealing with food waste. Thus, food waste reduction campaigns could focus on three outcomes: (1) reducing food waste; (2) reusing unconsumed food; and (3) recycling food [58]. 
Alternative consumption models, and the rise of the sharing economy, have made food sharing a method of food waste reduction, a measure which can now also be supported through the use of digital applications [59,60]. Morone et al. [61] researched the results of the food wasting behavior of students, living in private shared flats, who were instructed to purchase, cook, and consume food collectively. The authors found that, in order for these measures to have a positive impact on the reduction of food waste, three key enablers are needed: (1) environmentally friendly behavior and economic awareness; (2) skills; and (3) collaborative behaviors [61]. Reynolds et al. [23] proposed a guideline for food waste interventions that includes: (1) intervention design; (2) monitoring and measurement; (3) moderation and mediation; (4) reporting; and (5) systemic efforts.

Should food waste still occur, it should be valorized by being converted into useful products, such as chemicals, materials, and fuels $[62,63]$. For the valorization of food waste, the collaboration of different stakeholders from public and private institutions is important [64].

While some previous research shows that raising awareness among consumers may support food waste reduction [35,65], numerous studies, reviewed by Septianto et al. [3], have shown that emotional aspects must also be taken into account, aside from the cognitive aspects, such as education regarding food waste. Graham-Rowe et al. [46] concluded that even if avoiding negative emotions (e.g., guilt, regret) was at the basis of minimizing food waste, there could be other, potentially conflicting, personal goals (e.g., minimizing inconveniences) that might hinder attempts at household food waste reduction.

Online social networks have gained increased attention as a medium for awareness campaigns aimed at reducing food waste [66]. Goldsmith and Goldsmith [55] have stated that online social networks can have a similar effect as real interactions with opinion leaders. The research of Young et al. [67] analyzed the impact of a campaign led by a UK retailer that addressed food waste and contradicts the statement of Goldsmith and Goldsmith [55]. The initiative of the retailer was based on information in the retailer's magazine, in e-newsletters, and on Facebook. The results of the study have shown that people who took part in the Facebook initiative did not perform better, in terms of food waste reduction, than the control group [55].

Other methods that are used to deliver campaigns that aim to reduce food waste are websites, leaflets, posters, media and PR, waste challenges, community talks, regular press releases, providing tips and techniques, exhibitions, and others [24]. Most of the campaigns that were reviewed by the authors showed a statistically significant improvement.

A review of actions taken to reduce food waste at the consumer level, performed by Kim et al. [58], and Stöckli et al. [68], reveals that most of these actions were based on informing and educating consumers. Interventions that rely on informing the consumers have sometimes proven to be ineffective. In the study of Wansink and van Ittersum [69], informing the attendees of a health conference about the negative effect that large plates have on food waste did not change their behavior. On the other hand, the education campaign performed in a Portuguese university canteen managed to reduce plate waste by raising awareness and suggesting techniques to reduce food waste [24].

The research of Aschemann-Witzel et al. [21] points out the factors that influence information and capacity-building initiatives, such as collaboration between organizations and supply chain actors, timing, and competencies. The development and maintenance of these initiatives depended on the management of attention and achievement on a large scale, while successfully reaching consumers depended on having a positive focus and easiness [21].

With the advancement of new technologies, research has also been oriented towards how they can reduce food waste throughout the supply chain. Artificial intelligence, machine learning, big data analytics, and the Internet of Things have changed the paradigms of several business sectors but have also contributed to raising the efficiency of the public sector through their utilization for public policies [70]. Technologies, such as wireless 
sensors and the Internet of Everything, can not only contribute to ensuring the quality and safety of food, but can also send information to companies regarding preferences [71].

Assessing the effectiveness of food waste prevention measures is required in order to identify the initiatives that deliver the most relevant outcome. However, there are challenges in evaluating the effectiveness of prevention measures, mainly due to the difficulty of assessing the potential food waste reduction generated by them [72].

\section{Research Methodology}

The impact of the familiarity with awareness campaigns aimed at combating consumer food waste over consumer food-wasting behavior was analyzed based on 384 responses gathered through an online self-administered survey addressed to Romanian citizens. By "consumer food wasting behavior", we refer to: (1) the self-assessed quantity of food waste, and (2) the actions undertaken by the consumers to reduce their food waste in the past year. Thus, the respondents had to answer three questions: Q1, "How much food do you consider you waste?" (1-5 Likert-scale answers); Q2, "Are you familiar with awareness campaigns regarding food waste?" (Yes/No answers); and Q3, "Did you undertake actions to prevent food waste in the past year?" (Yes/No answers).

Demographic data was also collected on the gender, highest completed education levels, and monthly net income levels of the respondents. Moreover, the respondents were asked to give an example of at least one campaign aimed at raising awareness on food waste, a company/institution organizing such campaigns, or a situation where they came across this subject, even if they did not recall the name of a specific campaign or organization.

The data collection took place between the 1st of March and the 12th of June 2020. The sample size is in accordance with a 95\% confidence level with a 5\% margin of error.

The responses were analyzed in SPSS. The Pearson's chi-square test was used to determine the association between $\mathrm{Q} 1$ and Q2, Q1 and Q3, and Q2 and Q3, aided by the Cramer's V and Phi tests for determining the effect size in each of the cases. Regression analysis was used for assessing the impact of Q1, Q2, and Q3 over each other, as follows: (1) an ordinal probit regression model was used to assess the impact of the familiarity with awareness campaigns over the self-assessed quantity of wasted food; (2) a binomial probit regression model was used to assess the impact of the familiarity with awareness campaigns over the choice of taking action in reducing food waste; and (3) an ordinal probit regression model was used to assess the impact of the actions taken by the consumers to reduce their food waste over the self-assessed quantity of wasted food. The relationships of the demographic variables with Q1, Q2, and Q3, as well as between themselves, were measured through correlation and the difference of means and have been controlled for in the regression analysis.

The research methodology is also presented in Figure 1.

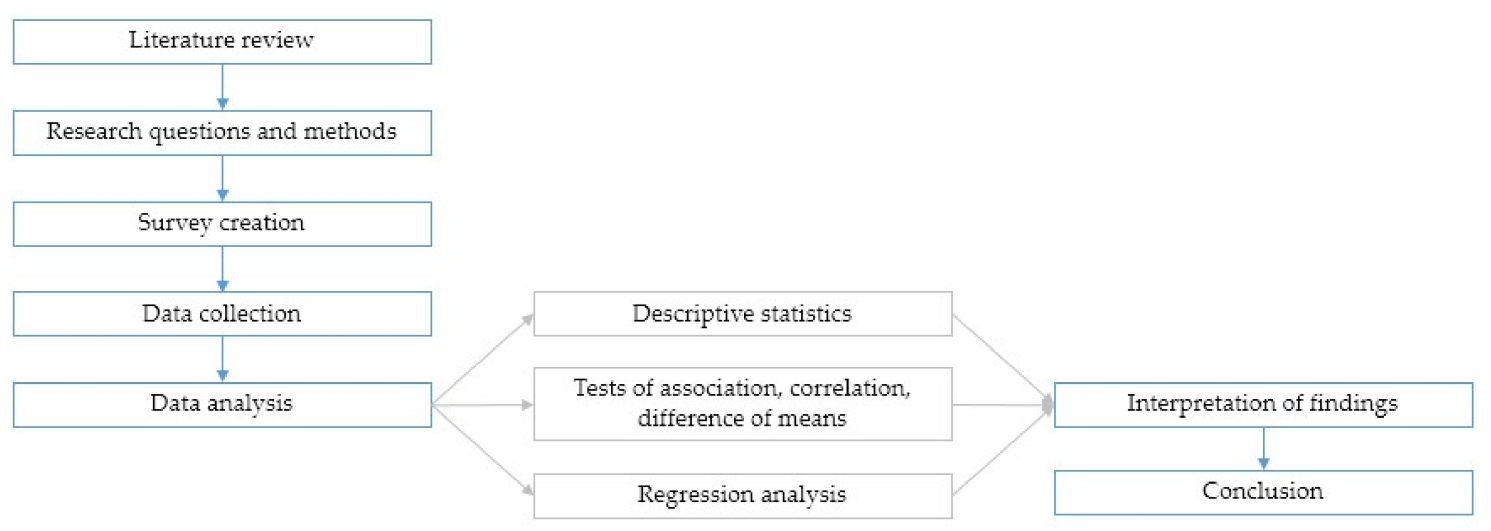

Figure 1. Research methodology diagram. Source: authors' research. 


\section{Results and Discussion}

\subsection{Descriptive Statistics}

Most participants $(66.7 \%)$ in the study were women. Almost half of the respondents had a college degree $(40.6 \%)$, and $75.5 \%$ of the total responses came from people with a monthly income of less than EUR 1499. There is a weak-to-moderate Spearman's rho correlation, $r_{s}=0.322, p<0.001, \mathrm{~N}=384$, between the education levels and the income levels of the respondents. However, no significant correlation was observed between the education levels or the income levels and the self-assessed food waste levels, or the actions undertaken by the respondents for reducing their food waste. Still, a weak correlation indicates that people with a higher level of education have a tendency to be informed on food waste issues, $r_{s}=0.133, p<0.009, \mathrm{~N}=384$. Moreover, women had a weak tendency to give higher ratings for their food waste quantity, $r_{s}=0.121, p<0.05$. Detailed descriptive statistics are available in Tables 1-3.

Table 1. Gender distribution of the respondents.

\begin{tabular}{ccccc}
\hline Category & Frequency & Percent & Valid Percent & Cumulative Percent \\
\hline Man & 128 & 33.3 & 33.3 & 33.3 \\
\hline Woman & 256 & 66.7 & 66.7 & 100.0 \\
\hline Total & 384 & 100.0 & 100.0 & \\
\hline
\end{tabular}

Source: authors' research.

Table 2. Highest completed education level of the respondents.

\begin{tabular}{ccccc}
\hline Category & Frequency & Percent & $\begin{array}{c}\text { Valid } \\
\text { Percent }\end{array}$ & Cumulative Percent \\
\hline $\begin{array}{c}\text { Lower secondary } \\
\text { education }\end{array}$ & 1 & 0.3 & 0.3 & 0.3 \\
\hline $\begin{array}{c}\text { Graduated from high } \\
\text { school }\end{array}$ & 85 & 22.1 & 22.1 & 22.4 \\
\hline $\begin{array}{c}\text { Graduated from college } \\
\text { Postgraduate studies }\end{array}$ & 156 & 40.6 & 40.6 & 63.0 \\
\hline Total & 142 & 37.0 & 37.0 & 100.0 \\
\hline Source: authors' research. & 384 & 100.0 & 100.0 &
\end{tabular}

Table 3. Monthly net income level of the respondents.

\begin{tabular}{ccccc}
\hline Category & Frequency & Percent & Valid Percent & Cumulative Percent \\
\hline Less than 1000 EUR & 172 & 44.8 & 44.8 & 44.8 \\
\hline 1000 EUR-1499 EUR & 118 & 30.7 & 30.7 & 75.5 \\
\hline 1500 EUR to 1999 EUR & 38 & 9.9 & 9.9 & 85.4 \\
\hline 2000 EUR to 2499 EUR & 22 & 5.7 & 5.7 & 91.1 \\
\hline 2500 EUR-2999 EUR & 13 & 3.4 & 3.4 & 94.5 \\
\hline 3000 EUR-3499 EUR & 3 & 0.8 & 0.8 & 95.3 \\
\hline 3500 EUR-3999 EUR & 4 & 1.0 & 1.0 & 96.4 \\
\hline 4000 EUR-4500 EUR & 2 & 0.5 & 0.5 & 96.9 \\
\hline More than 4500 EUR & 12 & 3.1 & 3.1 & 100.0 \\
\hline Total & 384 & 100.0 & 100.0 & \\
\hline
\end{tabular}


Only 66 out of the total 384 respondents gave an example of at least one campaign aimed at raising awareness on food waste, a company/institution organizing such campaigns, or a situation where they came across this subject even if they did not recall the name of a specific campaign or organization (e.g., televised news, friends' social media posts, people collecting food).

\subsection{Food Waste Awareness and Behavior}

\subsubsection{Answering RQ1}

The answers to Q1, "How much food do you consider you waste?" (1-5 Likert-scale answers), show that most of the participants of the study consider that they waste small and very small $(66.9 \%)$, and moderate $(28.9 \%)$ amounts of food. Only $2.9 \%$ of the respondents said they waste high quantities of food, and $1.3 \%$ said they waste very high quantities. However, previous studies have shown that people tend to underestimate the amount of food they waste [73]. However, the evaluation of the quantity of wasted food is not within the scope of this study. The results of the Pearson's chi-square test for RQ1 identified 20\% of cells, with an expected count less than 5 . In order to avoid this issue, the answers to Q1 were grouped into three categories: The " 1 " and " 2 " ratings were grouped as rating " 1 " (i.e., small quantity); rating " 3 " was relabeled as " 2 " (i.e., moderate quantity); while ratings " 4 " and " 5 " were grouped as rating " 3 " (i.e., large quantity). The new crosstabulation is available in Table 4, the Pearson's chi-square test in Table 5, and the clustered bar chart resulting from the crosstabulation is available in Figure 2.

Table 4. Crosstabulation: How much food do you consider you waste? * Are you familiar with awareness campaigns regarding food waste?

\begin{tabular}{|c|c|c|c|c|c|}
\hline \multirow[t]{2}{*}{ Question } & \multirow[t]{2}{*}{ Answer } & \multirow{2}{*}{ Statistics } & \multicolumn{2}{|c|}{$\begin{array}{l}\text { Are You Familiar with Awareness } \\
\text { Campaigns Regarding Food Waste? }\end{array}$} & \multirow{2}{*}{ Total } \\
\hline & & & Yes & No & \\
\hline \multirow{6}{*}{$\begin{array}{l}\text { How much food } \\
\text { do you consider } \\
\text { you waste? }\end{array}$} & \multirow{2}{*}{ I waste small quantities of food } & Count & 129 & 128 & 257 \\
\hline & & Expected Count & 119.1 & 137.9 & 257.0 \\
\hline & \multirow{2}{*}{ I waste moderate quantities of food } & Count & 44 & 67 & 111 \\
\hline & & Expected Count & 51.5 & 59.5 & 111.0 \\
\hline & \multirow{2}{*}{ I waste a large amount of food } & Count & 5 & 11 & 16 \\
\hline & & Expected Count & 7.4 & 8.6 & 16.0 \\
\hline & \multirow{2}{*}{ Total } & Count & 178 & 206 & 384 \\
\hline & & Expected Count & 178.0 & 206.0 & 384.0 \\
\hline
\end{tabular}

Source: authors' research.

Table 5. Pearson Chi-Square test for: How much food do you consider you waste? * Are you familiar with awareness campaigns regarding food waste?

\begin{tabular}{cccc}
\hline Statistics & Value & df & Asymptotic Significance (2-Sided) \\
\hline Pearson Chi-Square & $5.005^{\mathrm{a}}$ & 2 & 0.082 \\
\hline N of Valid Cases & 384 & & \\
\hline
\end{tabular}

Source: authors' research. ${ }^{\text {a }} 0$ cells $(0.0 \%)$ have expected count less than 5 . The minimum expected count is 7.42.

Although a difference in the observed counts can be seen between people who came in contact with campaigns to reduce food waste, and people who did not come across such campaigns, this difference is only among people who waste moderate-to-large amounts of food. There are more people who waste moderate-to-large quantities of food who are not aware of a food waste reduction campaign than there are people who waste these amounts of food and are aware of such campaigns. 


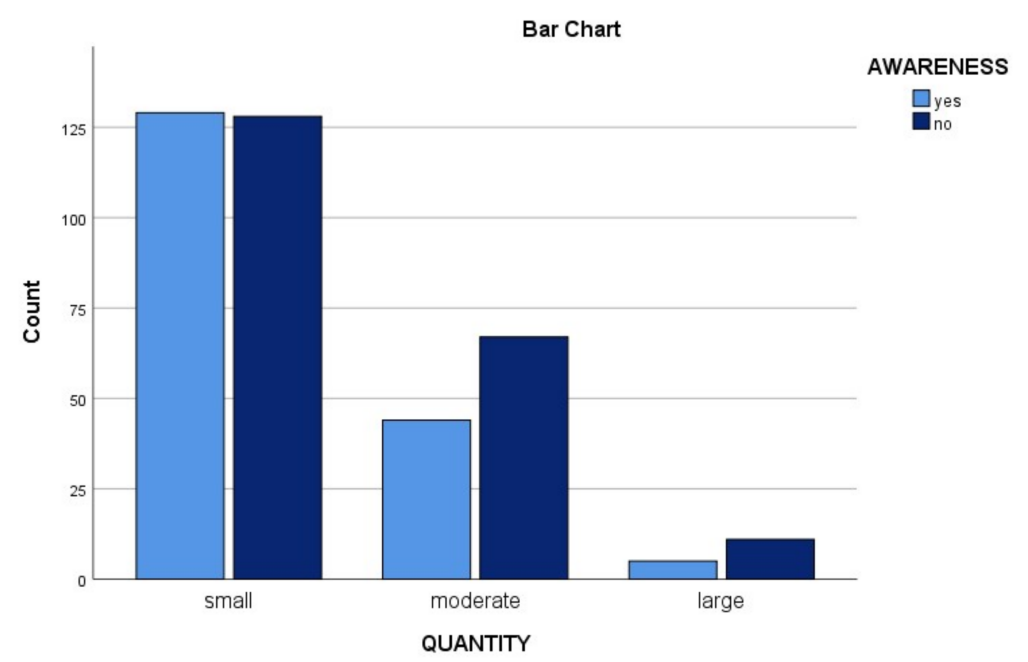

Figure 2. Clustered bar chart: How much food do you consider you waste? * Are you familiar with awareness campaigns regarding food waste? Source: authors' research.

However, the results of the Pearson's chi-square test, $\mathrm{X}^{2}(2, \mathrm{~N}=384)=5.005, p=0.082$, show that the difference between the observed and expected counts is not significant at the $95 \%$ confidence level and, thus, there is no significant association between the self-assessed amount of consumer food waste (Q1) and the consumers' familiarity with awareness campaigns (Q2). The Cramer's V $=0.114, p=0.082$, shows a weak effect size at the $90 \%$ confidence level. The Spearman's rho value $r_{s}=0.113, p<0.05, \mathrm{~N}=384$, shows a weak positive correlation between the self-assessed quantity of wasted food and the respondents' familiarity with awareness campaigns (i.e., people who are familiar with awareness campaigns have a slight inclination to also state that they are wasting smaller quantities of food).

An ordinal probit regression model was used to assess the impact of the familiarity with awareness campaigns (coded AWARENESS) over the self-assessed quantity of wasted food (coded QUANTITY), its results being available in Table 6. The procedure applies the cumulative probit to the QUANTITY variable values in descending order (i.e., from large to small quantities of food waste). The model represents a significant improvement in fit over an unconditional model with no predictors, $p<0.05$. The regression slope is positive, $\mathrm{B}=0.289, p<0.05$, people who are familiar with awareness campaigns being more likely to waste smaller quantities of food.

Table 6. Results of ordinal probit regression model for AWARENESS predicting QUANTITY.

\begin{tabular}{|c|c|c|c|c|c|c|c|c|c|c|c|}
\hline \multirow{2}{*}{\multicolumn{2}{|c|}{ Parameter }} & \multirow[t]{2}{*}{ B } & \multirow{2}{*}{$\begin{array}{l}\text { Std. } \\
\text { Error }\end{array}$} & \multicolumn{2}{|c|}{$\begin{array}{l}\text { 95\% Wald } \\
\text { Confidence } \\
\text { Interval }\end{array}$} & \multicolumn{3}{|c|}{ Hypothesis Test } & \multirow[t]{2}{*}{$\operatorname{Exp}(B)$} & \multicolumn{2}{|c|}{$\begin{array}{c}95 \% \text { Wald } \\
\text { Confidence Interval } \\
\text { for } \operatorname{Exp}(B)\end{array}$} \\
\hline & & & & Lower & Upper & $\begin{array}{c}\text { Wald } \\
\text { Chi-Square }\end{array}$ & df & Sig. & & Lower & Upper \\
\hline \multirow{2}{*}{ Threshold } & [quant = 3] & -1.326 & 0.2130 & -1.744 & -0.909 & 38.750 & 1 & 0.000 & 0.265 & 0.175 & 0.403 \\
\hline & [quant = 2] & -0.019 & 0.1970 & -0.405 & 0.367 & 0.009 & 1 & 0.922 & 0.981 & 0.667 & 1.443 \\
\hline \multicolumn{2}{|c|}{ AWARENESS } & 0.289 & 0.1289 & 0.037 & 0.542 & 5.035 & 1 & 0.025 & 1.335 & 1.037 & 1.719 \\
\hline \multicolumn{2}{|c|}{ (Scale) } & $1^{\mathrm{a}}$ & & & & & & & & & \\
\hline
\end{tabular}

Dependent Variable: QUANTITY. Model: (Threshold), AWARENESS. a. Fixed at displayed value. Source: authors' research.

The monthly net income and the education level were not deemed as statistically significant predictors for QUANTITY, $p>0.05$; however, women were more likely to report higher quantities of food waste, $\mathrm{t}(382)=-2.887, p<0.05$. As a result, the gender variable was introduced in the model, generating the results in Table 7. The AWARENESS slope 
changed from $B=0.289$ to $B=0.288, p<0.05$, while being a woman increased the chances for a higher self-assessed quantity of food waste, $B=-0.362, p<0.05$.

Table 7. Results of ordinal probit regression model for AWARENESS and gender predicting QUANTITY.

\begin{tabular}{|c|c|c|c|c|c|c|c|c|c|c|}
\hline \multirow{2}{*}{ Parameter } & \multirow{2}{*}{ B } & \multirow{2}{*}{$\begin{array}{l}\text { Std. } \\
\text { Error }\end{array}$} & \multicolumn{2}{|c|}{$\begin{array}{c}\text { 95\% Wald } \\
\text { Confidence } \\
\text { Interval }\end{array}$} & \multicolumn{3}{|c|}{ Hypothesis Test } & \multirow{2}{*}{$\operatorname{Exp}(B)$} & \multicolumn{2}{|c|}{$\begin{array}{c}95 \% \text { Wald } \\
\text { Confidence Interval } \\
\text { for } \operatorname{Exp}(B)\end{array}$} \\
\hline & & & Lower & Upper & $\begin{array}{c}\text { Wald } \\
\text { Chi-Square }\end{array}$ & df & Sig. & & Lower & Upper \\
\hline [quant = 3] & -1.959 & 0.3268 & -2.600 & -1.319 & 35.945 & 1 & 0.000 & 0.141 & 0.074 & 0.267 \\
\hline [quant = 2] & -0.630 & 0.3092 & -1.236 & -0.024 & 4.148 & 1 & 0.042 & 0.533 & 0.291 & 0.977 \\
\hline Gender & -0.362 & 0.1404 & -0.637 & -0.087 & 6.644 & 1 & 0.010 & 0.696 & 0.529 & 0.917 \\
\hline AWARENESS & 0.288 & 0.1294 & 0.034 & 0.541 & 4.939 & 1 & 0.026 & 1.333 & 1.035 & 1.718 \\
\hline (Scale) & $1^{a}$ & & & & & & & & & \\
\hline
\end{tabular}

Dependent Variable: QUANTITY. Model: (Threshold), gender, AWARENESS. a. Fixed at displayed value. Source: authors' research.

\subsubsection{Answering RQ2}

The Pearson's chi-square test for the second research question shows the association between people who came across awareness campaigns aimed at food waste reduction, and their past year's actions with regard to food waste reduction. The crosstabulation is available in Table 8, the Pearson's chi-square test in Table 9, and the clustered bar chart resulting from the crosstabulation is available in Figure 3.

Table 8. Crosstabulation: Did you undertake actions to prevent food waste in the last year? * Are you familiar with awareness campaigns regarding food waste?

\begin{tabular}{|c|c|c|c|c|c|}
\hline \multirow{2}{*}{ Question } & \multirow{2}{*}{ Answer } & \multirow{2}{*}{ Statistics } & \multicolumn{2}{|c|}{$\begin{array}{l}\text { Are You Familiar with Awareness } \\
\text { Campaigns Regarding Food Waste? }\end{array}$} & \multirow[t]{2}{*}{ Total } \\
\hline & & & Yes & No & \\
\hline \multirow{4}{*}{$\begin{array}{l}\text { Did you undertake actions } \\
\text { to prevent food waste in the } \\
\text { last year? }\end{array}$} & \multirow{2}{*}{ Yes } & Count & 135 & 119 & 254 \\
\hline & & Expected Count & 117.7 & 136.3 & 254.0 \\
\hline & \multirow{2}{*}{ No } & Count & 43 & 87 & 130 \\
\hline & & Expected Count & 60.3 & 69.7 & 130.0 \\
\hline \multirow{2}{*}{\multicolumn{2}{|c|}{ Total }} & Count & 178 & 206 & 384 \\
\hline & & Expected Count & 178.0 & 206.0 & 384.0 \\
\hline
\end{tabular}

Table 9. Pearson Chi-Square test for: Did you undertake actions to prevent food waste in the last year? ${ }^{*}$ Are you familiar with awareness campaigns regarding food waste?

\begin{tabular}{cccc}
\hline Statistics & Value & df & Asymptotic Significance (2-Sided) \\
\hline Pearson Chi-Square & $13.933^{\mathrm{a}}$ & 1 & 0.000 \\
\hline N of Valid Cases & 384 & & \\
\hline
\end{tabular}

Source: authors' research. ${ }^{\mathrm{a}} 0$ cells $(0.0 \%)$ have expected count less than 5 . The minimum expected count is $60.26 .{ }^{\mathrm{b}}$ Computed only for a $2 \times 2$ table.

It can be observed that the people who came across awareness campaigns regarding food waste had a tendency to say they took action for preventing their food waste in the past year, while people who are not familiar with awareness campaigns had a tendency to say they did not take any action for reducing food waste in the past year. Moreover, regardless of their awareness of food waste reduction campaigns, there were almost two 
times more respondents who said they did take action for preventing food waste in the past year (254) than the ones who did not (130).

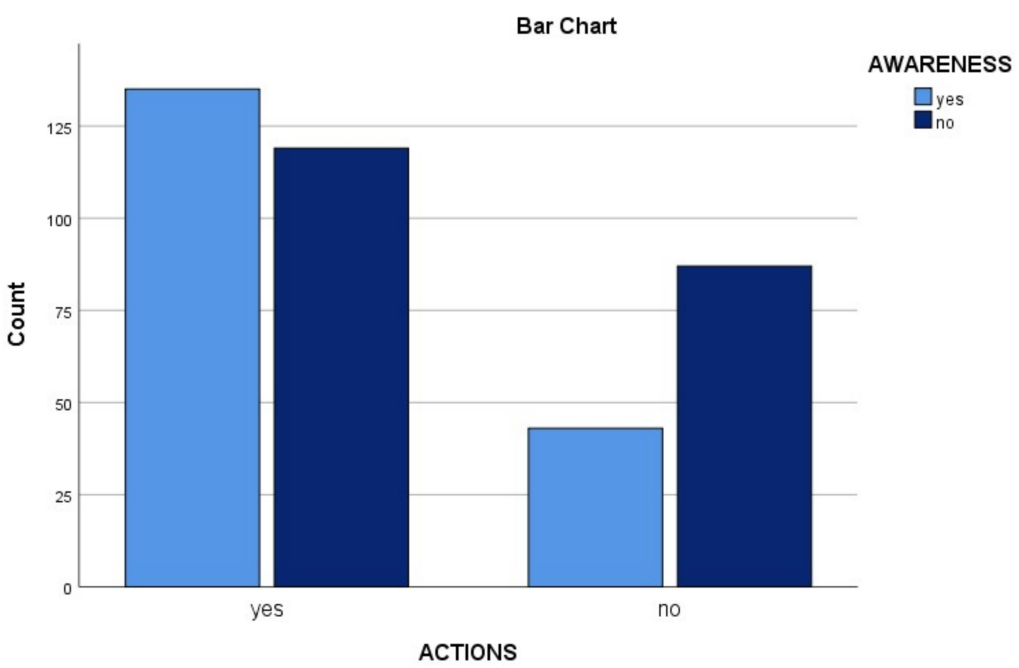

Figure 3. Clustered bar chart: Did you undertake actions to prevent food waste in the past year? * Are you familiar with awareness campaigns regarding food waste? Source: authors' research.

The result of the Pearson's chi-square test, $X^{2}(1, N=384)=13.933, p<0.001$, revealed a significant association between the respondents' familiarity with awareness campaigns (Q2) and their choice to take action for preventing their food waste in the past year (Q3). The Phi test $=0.190, p<0.001$ shows a weak effect size at the $99.9 \%$ confidence level. The Spearman's rho value, $r_{s}=0.190, p<0.001, \mathrm{~N}=384$, shows a weak correlation between the respondents' choice to take action for preventing their food waste in the past year and their familiarity with awareness campaigns.

A binomial probit regression model was used to assess the impact of the familiarity with awareness campaigns (coded AWARENESS) over the choice of taking action in reducing food waste (coded ACTION), its results being available in Table 10. The procedure models the choice of taking action as the response, treating the choice of not taking action as the reference category. The model represents a significant improvement in fit over an unconditional model with no predictors, $p<0.001$. The regression slope is positive, $\mathrm{B}=0.505, p<0.001$, with people who are familiar with awareness campaigns being more likely to take action in reducing their food waste in the past year. Gender, monthly net income, and the education level were not deemed as statistically significant predictors for ACTION, $p>0.05$.

Table 10. Results of binomial probit regression model for AWARENESS predicting ACTION.

\begin{tabular}{|c|c|c|c|c|c|c|c|c|c|c|}
\hline \multirow[t]{2}{*}{ Parameter } & \multirow[t]{2}{*}{ B } & \multirow{2}{*}{$\begin{array}{l}\text { Std. } \\
\text { Error }\end{array}$} & \multicolumn{2}{|c|}{$\begin{array}{l}95 \% \text { Wald } \\
\text { Confidence Interval }\end{array}$} & \multicolumn{3}{|c|}{ Hypothesis Test } & \multirow[t]{2}{*}{$\operatorname{Exp}(B)$} & \multicolumn{2}{|c|}{$\begin{array}{c}95 \% \text { Wald } \\
\text { Confidence Interval } \\
\text { for } \operatorname{Exp}(B)\end{array}$} \\
\hline & & & Lower & Upper & $\begin{array}{c}\text { Wald } \\
\text { Chi-Square }\end{array}$ & df & Sig. & & Lower & Upper \\
\hline (Intercept) & -0.309 & 0.2037 & -0.709 & 0.090 & 2.306 & 1 & 0.129 & 0.734 & 0.492 & 1.094 \\
\hline AWARENESS & 0.505 & 0.1353 & 0.240 & 0.771 & 13.947 & 1 & 0.000 & 1.658 & 1.271 & 2.161 \\
\hline (Scale) & $1^{\mathrm{a}}$ & & & & & & & & & \\
\hline
\end{tabular}

Dependent Variable: ACTION. Model: (Intercept), AWARENESS. a. Fixed at displayed value. Source: authors' research. 


\subsubsection{Answering RQ3}

Tables 11 and 12, and Figure 4 look at the association between the self-assessed amount of food waste (Q1) and the respondents' actions for preventing their food waste in the past year (Q3).

Table 11. Crosstabulation: Did you undertake actions to prevent food waste in the last year? * How much food do you consider you waste?

\begin{tabular}{|c|c|c|c|c|c|c|}
\hline \multirow{2}{*}{ Question } & \multirow{2}{*}{ Answer } & \multirow{2}{*}{ Statistics } & \multicolumn{3}{|c|}{ How Much Food Do You Consider You Waste? } & \multirow{2}{*}{ Total } \\
\hline & & & Small q. & Moderate q. & Large q. & \\
\hline \multirow{4}{*}{$\begin{array}{c}\text { Did you undertake } \\
\text { actions to prevent } \\
\text { food waste in the last } \\
\text { year? }\end{array}$} & \multirow{2}{*}{ Yes } & Count & 183 & 64 & 7 & 254 \\
\hline & & Expected Count & 170.0 & 73.4 & 10.6 & 254.0 \\
\hline & \multirow{2}{*}{ No } & Count & 74 & 47 & 9 & 130 \\
\hline & & Expected Count & 87.0 & 37.6 & 5.4 & 130.0 \\
\hline \multirow{2}{*}{\multicolumn{2}{|c|}{ Total }} & Count & 257 & 111 & 16 & 384 \\
\hline & & Expected Count & 257.0 & 111.0 & 16.0 & 384.0 \\
\hline
\end{tabular}

Table 12. Pearson Chi-Square test for: Did you undertake actions to prevent food waste in the last year? ${ }^{*}$ How much food do you consider you waste?

\begin{tabular}{cccc}
\hline Statistics & Value & df & Asymptotic Significance (2-Sided) \\
\hline Pearson Chi-Square & $10.094^{\mathrm{a}}$ & 2 & 0.006 \\
\hline N of Valid Cases & 384 & & \\
\hline
\end{tabular}

Source: authors' research. ${ }^{\text {a }} 0$ cells $(0.0 \%)$ have expected count less than 5 . The minimum expected count is 5.42 .

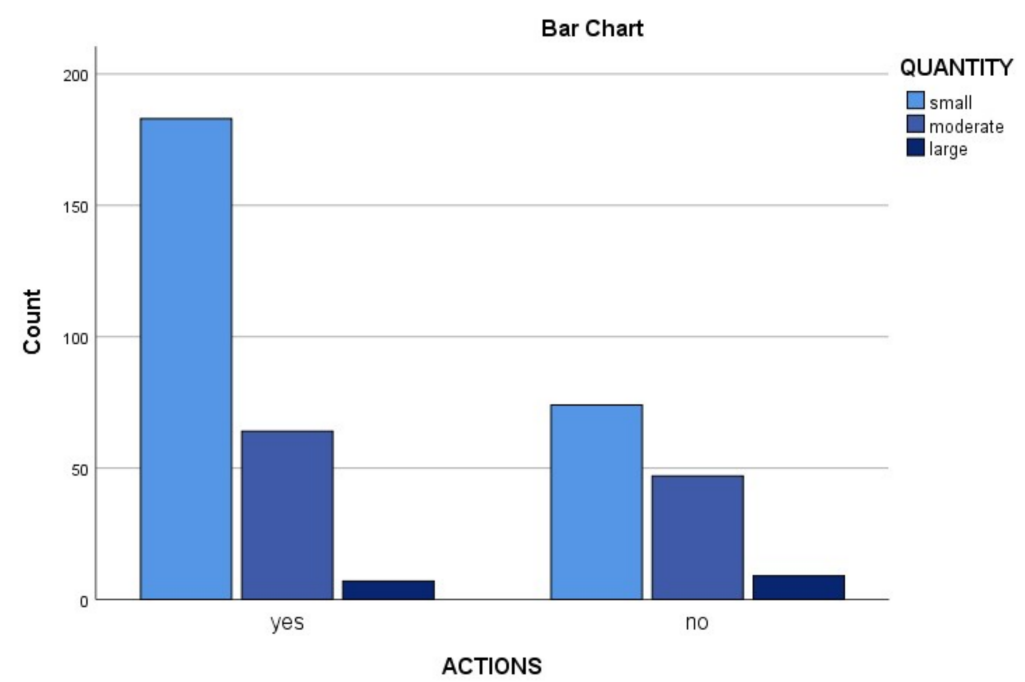

Figure 4. Clustered bar chart: Did you undertake actions to prevent food waste in the last year? * How much food do you consider you waste? Source: authors' research.

Almost half of the respondents (183) reported that they took action in the past year to reduce their food waste, as well as that their food waste amount was small.

The results of the Pearson's chi-square test, $\mathrm{X}^{2}(2, \mathrm{~N}=384)=10.094, p<0.01$, show that there is a significant association between the self-assessed amount of food waste and the respondents' actions for preventing their food waste in the past year. The Cramer's V $=0.162$, $p=0.006$ shows a weak effect size at the $99 \%$ confidence level. The Spearman's rho value, $r_{s}=0.158, p=0.002, \mathrm{~N}=384$, shows a weak correlation between the self-assessed quantity of wasted food and the respondents' actions for preventing their food waste in the past year. 
An ordinal probit regression model was used to assess the impact of actions taken by the respondents to reduce their food waste in the past year (coded ACTION) over the self-assessed quantity of wasted food (coded QUANTITY). Moreover, as previously discussed, the monthly net income and the education level were not deemed as statistically significant predictors for QUANTITY, $p>0.05$; however, women were more likely to report higher quantities of food waste, $\mathrm{t}(382)=-2.887, p<0.05$. As a result, the gender variable was introduced in the model.

The procedure applies the cumulative probit to the QUANTITY variable values in descending order (i.e., from large to small quantities of food waste). The model represents a significant improvement in fit over an unconditional model with no predictors, $p<0.05$, and is available in Table 13. It shows that people who took action in the past year to reduce their food waste were more likely to report smaller quantities of food waste, $\mathrm{B}=0.445$, $p<0.05$, while being a woman increases the chances for a higher self-assessed quantity of food waste, $\mathrm{B}=-0.401, p<0.05$.

Table 13. Results of ordinal probit regression model for ACTION and gender predicting QUANTITY.

\begin{tabular}{|c|c|c|c|c|c|c|c|c|}
\hline \multirow{2}{*}{\multicolumn{2}{|c|}{ Parameter }} & \multirow{2}{*}{ B } & \multirow{2}{*}{ Std. Error } & \multicolumn{2}{|c|}{$\begin{array}{c}\text { 95\% Wald Confidence } \\
\text { Interval }\end{array}$} & \multicolumn{3}{|c|}{ Hypothesis Test } \\
\hline & & & & Lower & Upper & $\begin{array}{c}\text { Wald } \\
\text { Chi-Square }\end{array}$ & df & Sig. \\
\hline \multirow{2}{*}{ Threshold } & [quant = 3] & -1.728 & 0.3317 & -2.378 & -1.078 & 27.139 & 1 & 0.000 \\
\hline & [quant = 2] & -0.379 & 0.3167 & -1.000 & 0.241 & 1.436 & 1 & 0.231 \\
\hline \multicolumn{2}{|c|}{ ACTION } & 0.445 & 0.1334 & 0.184 & 0.707 & 11.138 & 1 & 0.001 \\
\hline \multicolumn{2}{|c|}{ Gender } & -0.401 & 0.1416 & -0.678 & -0.123 & 8.000 & 1 & 0.005 \\
\hline \multicolumn{2}{|c|}{ (Scale) } & $1^{a}$ & & & & & & \\
\hline
\end{tabular}

Dependent Variable: QUANTITY. Model: (Threshold), ACTION, gender. ${ }^{a}$ Fixed at displayed value. Source: authors' research.

\section{Conclusions}

Awareness campaigns for the reduction of food waste could have a positive impact on consumers' initiatives to limit the quantity of wasted food.

Firstly, there is a significant association between the respondents' familiarity with awareness campaigns and their choice to take action for preventing their food waste in the past year, people who are familiar with awareness campaigns being more likely to take action to reduce their food waste, $\mathrm{B}=0.505, p<0.001$.

Secondly, no significant association was found between the self-assessed amount of consumer food waste and the consumers' familiarity with awareness campaigns; however, being familiar with awareness campaigns aimed at reducing food waste determines an expected reduction in the self-assessed quantity of food waste, $\mathrm{B}=0.288, p<0.05$, while being a woman increases the chances for a higher self-assessed quantity of food waste, $\mathrm{B}=-0.362, p<0.05$.

Finally, there is a significant association between the self-reported quantity of food waste and the respondents' choice to take action for preventing food waste in the past year, people who took action for reducing their food waste being more likely to report smaller quantities of food waste, $B=0.445, p<0.05$, while being a woman increases the chances for a higher self-assessed quantity of food waste, $\mathrm{B}=-0.401, p<0.05$.

Considering that only 7 respondents out of $384(1.8 \%)$ said they are wasting large quantities of food, despite taking action to reduce their food waste in the past year, it might be the case that most respondents already self-assessed their food waste as small to moderate, regardless of their familiarity with food waste campaigns, and only their additional actions to reduce their food waste are linked with coming across food waste reduction campaigns. 
This paper has contributed to the scientific literature regarding the effects of food waste campaigns by analyzing a preventive measure to reduce food waste, in a country where food waste awareness has only recently become a subject of interest for policymakers and citizens. Since the results of the study show that people who have come across awareness campaigns have taken actions in order to reduce the amount of food that they waste, organizations, companies, and public institutions could focus next on practical examples, tools, and techniques for food waste reduction.

The limitations of the study come from relying on self-assessment questions, as well as from having a narrow geographical reach and an unbalanced mix of respondents.

The effect of food waste campaigns on the reduction of food waste should be further studied. Although a difficult undertaking, future research could focus on educational campaigns, and analyze food waste prior and after the campaign. Another line of research should focus on the effectiveness of the different tools used in food waste campaigns.

Measuring the impact of these campaigns on consumer behavior could also rely on technologies that are expected to be increasingly adopted in the following years. Moreover, it is advisable to identify the success factors of any such initiatives undertaken to prevent and reduce food waste in correlation with their results on changing consumer behavior.

Author Contributions: Conceptualization, C.C., I.B. and F.B.; Methodology, C.C., I.B. and F.B.; Validation, C.C., I.B. and F.B.; Formal analysis, C.C. and I.B.; Investigation, C.C. and I.B.; Resources, C.C. and I.B.; Data curation, C.C. and I.B.; Writing-original draft preparation, C.C., I.B. and F.B.; Writing-review and editing, C.C. and I.B.; Visualization, C.C. and I.B.; Supervision, C.C.; Project administration, C.C. and I.B.; Funding acquisition, C.C. All authors have read and agreed to the published version of the manuscript.

Funding: This research has been funded by Archmara SRL \& Dictie.ro.

Institutional Review Board Statement: Not applicable.

Informed Consent Statement: Not applicable.

Data Availability Statement: Not applicable.

Conflicts of Interest: The authors declare no conflict of interest.

\section{References}

1. FAO. Food Wastage Footprint: Impacts on Natural Resources; Summary Report; Food and Agriculture Organization of the United Nations: Rome, Italy, 2013; Available online: http:/ /www.fao.org/3/i3347e/i3347e.pdf (accessed on 16 April 2021).

2. Parizeau, K.; von Massow, M.; Martin, R. Household-level dynamics of food waste production and related beliefs, attitudes, and behaviours in Guelph, Ontario. Waste Manag. 2015, 35, 207-217. [CrossRef] [PubMed]

3. Septianto, F.; Kemper, J.A.; Northey, G. Thanks, but no thanks: The influence of gratitude on consumer awareness of food waste. J. Clean. Prod. 2020, 258, 120591. [CrossRef]

4. European Commission. EU Platform on Food Losses and Food Waste. Available online: https://ec.europa.eu/food/safety/foodwaste/eu-actions-against-food-waste/eu-platform-food-losses-and-food-waste_ro (accessed on 16 April 2021).

5. Romanian Ministry of Agriculture. Year 2014-The Year of Reducing Food Waste. Available online: https://www.madr.ro/docs / ind-alimentara/risipa_alimentara/anul-2014-anul-combaterii-risipei-alimentare.pdf (accessed on 9 September 2021).

6. Romanian Ministry of Agriculture. Food Waste. Available online: https://www.madr.ro/risipa-alimentara.html (accessed on 9 September 2021).

7. Gustavsson, J.; Cederberg, C.; Sonesson, U. Global Food Losses and Food Waste: Extent, Causes and Prevention; Food and Agriculture Organization of the United Nations; FAO: Rome, Italy, 2011; Available online: http://www.fao.org/3/i2697e/i2697e.pdf (accessed on 16 April 2021).

8. Ju, M.; Osako, M.; Harashina, S. Food loss rate in food supply chain using material flow analysis. Waste Manag. 2017, 61, 443-454. [CrossRef] [PubMed]

9. European Commission. Final Report_Preparatory Study on Food Waste across EU 27; BIO Intelligence Service: Paris, France, 2010; Available online: https:/ / ec.europa.eu/environment/eussd/pdf/bio_foodwaste_report.pdf (accessed on 16 April 2021).

10. Parfitt, J.; Barthel, M.; Macnaughton, S. Food waste within food supply chains: Quantification and potential for change to 2050. Philos. Trans. R. Soc. B 2010, 365, 3065-3081. [CrossRef]

11. Beretta, C.; Stoessel, F.; Baier, U.; Hellweg, S. Quantifying food losses and the potential for reduction in Switzerland. Waste Manag. 2013, 33, 764-773. [CrossRef] 
12. Garcia-Herrero, I.; Hoehn, D.; Margallo, M.; Laso, J.; Bala, A.; Batlle-Bayer, L.; Fullana, P.; Vazquez-Rowe, I.; Gonzalez, M.; Durá, M.; et al. On the estimation of potential food waste reduction to support sustainable production and consumption policies. Food Policy 2018, 80, 24-38. [CrossRef]

13. Hebrok, M.; Heidenstrøm, N. Contextualising food waste prevention-Decisive moments within everyday practices. J. Clean Prod. 2019, 210, 1435-1448. [CrossRef]

14. Leverenz, D.; Moussawel, S.; Maurer, C.; Hafner, G.; Schneider, F.; Schmidt, T.; Kranert, M. Quantifying the prevention potential of avoidable food waste in households using a self-reporting approach. Resour. Conserv. Recycl. 2019, 150, 104417. [CrossRef]

15. Romani, S.; Grappi, S.; Bagozzi, R.P.; Barone, A.M. Domestic food practices: A study of food management behaviors and the role of food preparation planning in reducing waste. Appetite 2018, 121, 215-227. [CrossRef] [PubMed]

16. Schanes, K.; Dobernig, K.; Gözet, B. Food waste matters-A systematic review of household food waste practices and their policy implications. J. Clean. Prod. 2018, 182, 978-991. [CrossRef]

17. Visschers, V.H.M.; Wickli, N.; Siegrist, M. Sorting out food waste behaviour: A survey on the motivators and barriers of self-reported amounts of food waste in households. J. Environ. Psychol. 2016, 45, 66-78. [CrossRef]

18. Graham-Rowe, E.; Jessop, D.C.; Sparks, P. Predicting household food waste reduction using an extended theory of planned behavior. Resources. Conserv. Recycl. 2015, 101, 194-202. [CrossRef]

19. Cicatiello, C.; Franco, S.; Pancino, B.; Blasi, E. The value of food waste: An exploratory study on retailing. J. Retail. Consum. Serv. 2016, 30, 96-104. [CrossRef]

20. Papargyropoulou, E.; Lozano, R.; Steinberger, J.K.; Wright, N.; Bin Ujang, Z. The food waste hierarchy as a framework for the management of food surplus and food waste. J. Clean. Prod. 2014, 76, 106-115. [CrossRef]

21. Aschemann-Witzel, J.; de Hooge, I.E.; Rohm, H.; Normann, A.; Bonzanini Bossle, M.; Grønhøj, A.; Oostindjer, M. Key characteristics and success factors of supply chain initiatives tackling consumer-related food waste-A multiple case study. J. Clean. Prod. 2017, 155 Pt 2, 33-45. [CrossRef]

22. FAO. Toolkit. Reducing the Food Wastage Footprint. 2013. Available online: http://www.fao.org/3/i3342e/i3342e.pdf (accessed on 16 April 2021).

23. Reynolds, C.; Goucher, L.; Quested, T.; Bromley, S.; Gillick, S.; Wells, V.; Evans, D.; Koh, L.; Carlsson Kanyama, A.; Katzeff, C.; et al. Review: Consumption-stage food waste reduction interventions-What works and how to design better interventions. Food Policy 2019, 83, 7-27. [CrossRef]

24. Zamri, G.; Azizal, N.; Nakamura, S.; Okada, K.; Nordin, N.; Othman, N.; Akhir, F.N.M.D.; Sobian, A.; Kaida, N.; Hara, H. Delivery, impact and approach of household food waste reduction campaigns. J. Clean. Prod. 2020, 246, 118969. [CrossRef]

25. Ellison, B.; Savchenko, O.; Nikolaus, C.; Duff, B. Every plate counts: Evaluation of a food waste reduction campaign in a university dining hall. Resour. Conserv. Recycl. 2019, 144, 276-284. [CrossRef]

26. Pinto, R.S.; dos Santo Pinto, R.M.; Melo, F.F.S.; Campos, S.S.; Marques-dos-Santos Cordovil, C. A simple awareness campaign to promote food waste reduction in a University canteen. Waste Manag. 2018, 76, 28-38. [CrossRef] [PubMed]

27. Gavorek, C.; Kaur, B.; Mistry, A. Effectiveness of an Awareness Campaign on Plate Food Waste Habits in an Institutional Foodservice Establishment. J. Acad. Nutr. Diet. 2018, 118, A51. [CrossRef]

28. Pocol, C.; Pinoteau, M.; Amuza, A.; Burlea-Schiopoiu, A.; Glogovețan, A. Food waste behavior among Romanian consumers: A cluster analysis. Sustainability 2020, 12, 9708. [CrossRef]

29. Dumitru, I.; Burghiu, A. Romanian food waste analysis. In New Trends in Sustainable Business and Consumption; Editura ASE: Bucharest, Romania, 2019.

30. Ghinea, C.; Ghiuta, O. Household food waste generation: Young consumers' behaviour, habits and attitudes. Int. J. Environ. Sci. Technol. 2018, 16, 2185-2200. [CrossRef]

31. Lombardi, M.; Costantino, M. A social innovation model for reducing food waste: The case study of an Italian non-profit organization. Adm. Sci. 2020, 10, 45. [CrossRef]

32. FAO. Sustainable Development Goals; Food and Agriculture Organization of the United Nations: Rome, Italy, 2021; Available online: http:/ / www.fao.org/sustainable-development-goals/indicators/1231/en/ (accessed on 16 April 2021).

33. UNEP. Food Waste Index Report 2021. United Nations Environment Programme. 2021. Available online: https://www.unep. org/resources/report/unep-food-waste-index-report-2021 (accessed on 23 April 2021).

34. FAO. Food Wastage Footprint and Climate Change; Food and Agriculture Organization of the United Nations: Rome, Italy, 2015; Available online: http:/ / www.fao.org/3/bb144e/bb144e.pdf (accessed on 16 April 2021).

35. Eriksson, M.; Giovannini, S.; Ghosh, R. Is there a need for greater integration and shift in policy to tackle food waste? Insights from a review of European Union legislations. SN Appl. Sci. 2020, 2, 1347. [CrossRef]

36. Antoneac, A.; Petre, I.; Nica, M.; Iana, A. Food waste analysis in Romania in comparison to the European Union. Annals of Faculty of Economics. 2019, Volume 1. Available online: https://econpapers.repec.org/article/orajournl/v_3a1_3ay_3a2019_3ai_ 3a1_3ap_3a227-239.htm (accessed on 20 April 2021).

37. Parlamentul României. Law 217/2016 LEGEA nr. 217 din 17 Noiembrie 2016 (*Republicată*). 2019. Available online: http: / / legislatie.just.ro/Public/DetaliiDocument/183792 (accessed on 9 September 2021).

38. Statista. Annual Food Waste Produced Per Capita Worldwide in 2019, by Sector. 2021. Available online: https:/ / www.statista. com/statistics/1219850/global-food-waste-by-sector-per-capita/ (accessed on 23 April 2021). 
39. Eurostat. Inability to Afford a Meal with Meat, Chicken, Fish (or Vegetarian Equivalent) Every Second Day-EU-SILC Survey. 2021. Available online: https://ec.europa.eu/eurostat/databrowser/view/ilc_mdes03/default/table?lang=en (accessed on 9 September 2021).

40. The World Counts. People Who Died from Hunger. 2021. Available online: https://www.theworldcounts.com/challenges/ people-and-poverty/hunger-and-obesity/how-many-people-die-from-hunger-each-year/story (accessed on 23 April 2021).

41. Ionita, I. Click to Feed. Mobile phone applications' role in improving food access in Romania. Interações 2018, 34, 161-187. [CrossRef]

42. Iorga, S.; Apostol, L.; Belc, N.; Mosoiu, C.; Berca, L.; Niculae, O.; Popa, M. Profile of high risk wasting food consumer in Romania, Scientific Bulletin. Ser. F Biotechnol. 2017, 21, 301-307.

43. Dumitru, O.; Iorga, S.; Sanmartin, A. Food waste impact on Romanian households. Rom. Biotechnol. Lett. 2021, 26, 2207-2213. [CrossRef]

44. INSSE. Indicele Preturilor de Consum—Lunar. Institutul Național de Statistică. 2021. Available online: http:/ / statistici.insse.ro / shop / ?page=ipc1 (accessed on 23 April 2021).

45. INSSE. Castigul Salarial Mediu net Lunar pe Total Economie in anii 1991-2021. 2021. Available online: https://insse.ro/cms/ro/ content/c\%C3\%A2\%C8\%99tiguri-salariale-din-1991-serie-lunar\%C4\%83 (accessed on 23 April 2021).

46. Graham-Rowe, E.; Jessop, D.C.; Sparks, P. Identifying motivations and barriers to minimising household food waste. Resour. Conserv. Recycl. 2014, 84, 15-23. [CrossRef]

47. Blichfeldt, B.S.; Mikkelsen, M.; Gram, M. When it stops being food: The edibility, ideology, procrastination, objectification and internalization of household food waste. Food Cult. Soc. 2015, 18, 89-105. [CrossRef]

48. Cantaragiu, R. The impact of gender on food waste at the consumer level. Stud. Univ. Vasile Goldis Arad Econ. Ser. 2019, 29, 41-57. [CrossRef]

49. European Parliament. Report on How to Avoid Food Wastage: Strategies for a More Efficient Food Chain in the EU. European Parliament. 2011. Available online: https:/ / www.europarl.europa.eu/doceo/document/A-7-2011-0430_EN.html (accessed on 23 April 2021).

50. Gheorghescu, I.; Balan, I. Managing, minimizing and preventing food waste from Romania in the European context. Lucr. Stiintifice Manag. Agric. 2019, 21, 58.

51. Lee, K.C. Grocery shopping, food waste, and the retail landscape of cities: The case of Seoul. J. Clean. Prod. 2018, 172, 325-334. [CrossRef]

52. Minton, E.; Johnson, K.; Vizcaino, M.; Wharton, C. Is it godly to waste food? How understanding consumers' religion can help reduce consumer food waste. J. Consum. Aff. 2020, 54, 1246-1269. [CrossRef]

53. Wakefield, A.; Axon, S. "I'm a bit of a waster": Identifying the enablers of, and barriers to, sustainable food waste practices. J. Clean. Prod. 2020, 275, 122803. [CrossRef]

54. Janssens, K.; Lambrechts, W.; van Osch, A.; Semeijn, J. How Consumer Behavior in Daily Food Provisioning Affects Food Waste at Household Level in The Netherlands. Foods 2019, 8, 428. [CrossRef]

55. Goldsmith, E.B.; Goldsmith, R.E. Social influence and sustainability in households. Int. J. Consum. Stud. 2011, 35, 117-121. [CrossRef]

56. Auld, G.; Mallett, A.; Burlica, B.; Nolan-Poupart, F.; Slater, R. Evaluating the effects of policy innovations: Lessons from a systematic review of policies promoting low-carbon technology. Glob. Environ. Chang. 2014, 29, 444-458. [CrossRef]

57. Briggs, H.; Lindeberg, J.D.; Rein, A.; Chorn, B.; Tanger, K. The ReFED Roadmap to Reducing Food Waste, Biocycle. June 2016, p. 57. Available online: https://refed.com/articles/the-refed-roadmap-to-reducing-food-waste/ (accessed on 16 April 2021).

58. Kim, J.; Rundle-Thiele, S.; Knox, K.; Burke, K. Consumer perspectives on household food waste reduction campaigns. J. Clean. Prod. 2020, 243, 118608. [CrossRef]

59. Farr-Wharton, G.; Choi, J.; Foth, M. Food talks back: Exploring the role of mobile applications in reducing domestic food wastage. In Proceedings of the 26th Australian Computer-Human Interaction Conference on Designing Futures: The Future of Design; Loke, L., Leong, T., O’Hara, K., Wadley, G., Robertson, T., Eds.; Association for Computing Machinery: New York, NY, USA, 2014; pp. 352-361.

60. Ganglbauer, E.; Fitzpatrick, G.; Subasi, Ö.; Güldenpfennig, F. Think globally, act locally: A case study of a free food sharing community and social networking. In Proceedings of the Computer Supported Cooperative Work and Social Computing, Baltimore, MD, USA, 15-19 February 2014; pp. 911-921.

61. Morone, P.; Falcone, P.; Imbert, E.; Morone, A. Does food sharing lead to food waste reduction? An experimental analysis to assess challenges and opportunities of a new consumption model. J. Clean. Prod. 2018, 185, 749-760. [CrossRef]

62. Arancon, R.; Lin, C.; Chan, K.; Kwan, T.; Luque, R. Advances on waste valorization: New horizons for a more sustainable society. Energy Sci. Eng. 2013, 1, 53-71. [CrossRef]

63. Kannah, R.Y.; Merrylin, J.; Poornima Devi, T.; Kavitha, S.; Sivashanmugam, P.; Kumar, G.; Rajesh Banu, J. Food waste valorization: Biofuels and value added product recovery. Bioresour. Technol. Rep. 2020, 11, 100524. [CrossRef]

64. Morone, P.; Falcone, P.; Tartiu, V. Food waste valorisation: Assessing the effectiveness of collaborative research networks through the lenses of a COST action. J. Clean. Prod. 2019, 238, 117868. [CrossRef]

65. Pearson, D.; Perera, A. Reducing Food Waste: A Practitioner Guide Identifying Requirements for an Integrated Social Marketing Communication Campaign. Soc. Mark. Q. 2018, 24, 45-57. [CrossRef] 
66. Lovejoy, K.; Saxton, G.D. Information, community, and action: How nonprofit organizations use social media. J. Comput. Mediat. Commun. 2012, 17, 337-353. [CrossRef]

67. Young, W.; Russel, S.V.; Robinson, C.A.; Barkemeyer, R. Can social media be a tool for reducing consumers' food waste? A behaviour change experiment by a UK retailer. Resour. Conserv. Recycl. 2017, 117, 195-203. [CrossRef]

68. Stöckli, S.; Niklaus, E.; Dorn, M. Call for testing interventions to prevent consumer food waste. Resour. Conserv. Recycl. 2018, 136, 445-462. [CrossRef]

69. Wansink, B.; van Ittersum, K. Portion size me: Plate-size induced consumption norms and win-win solutions for reducing food intake and waste. J. Exp. Psychol. Appl. 2013, 19, 320-332. [CrossRef] [PubMed]

70. Eggers, W.D.; Turley, M.; Kishnani, P. The Regulator's New Toolkit. Technologies and Tactics for Tomorrow's Regulator, Deloitte Insights. 18 October 2018. Available online: https://www2.deloitte.com/us/en/insights/industry/public-sector/reducingcompliance-costs-with-regtech.html (accessed on 16 April 2021).

71. Vanderroost, M.; Ragaert, P.; Verwaeren, J.; De Meulenaer, B.; De Baets, B.; Devlieghere, F. The digitization of a food package's life cycle: Existing and emerging computer systems in the logistics and post-logistics phase. Comput. Ind. 2017, 87, 1-14. [CrossRef]

72. Kosseva, M.R.; Webb, C. Food Industry Wastes: Assessment and Recuperation of Commodities, 2nd ed.; Academic Press: London, UK, 2020.

73. Giordano, C.; Piras, S.; Boschini, M.; Falasconi, L. Are questionnaires a reliable method to measure food waste? A pilot study on Italian households. Br. Food J. 2018, 120, 2885-2897. [CrossRef] 